\title{
A digital elevation model of the Antarctic ice sheet derived from ERS-1 altimeter data and comparison with terrestrial measurements
}

\author{
JONATHAN L. BAMBER \\ Mullard Space Science Laboratory, Department of Space and Climate Physics, University College London, \\ Holmbury St Mary, Dorking, Surrey RH5 6NT, England
}

\begin{abstract}
The launch of ERS-1 provides coverage, by satellite altimetry, of $80 \%$ of the Antarctic ice sheet, allowing topographic mapping of areas which previously had a dearth of accurate elevation data. Four $35 \mathrm{~d}$ repeat cycles of fastdelivery altimeter data were used in this study, comprising a total of approximately 1000000 height estimates. About $40 \%$ of these were rejected during a careful filtering procedure designed to remove erroneous values caused by poor tracking or complete loss of the returned echo. The OSU-91A geopotential model was used to convert ellipsoidal elevations to geoidal values. Corrections for surface slope were applied and a Digital Elevation Model (DEM) was produced with a grid spacing of $20 \mathrm{~km}$.

The precision of the data was assessed from an analysis of crossing points of ascending and descending tracks. For 43864 cross-overs, the standard deviation was $6.8 \mathrm{~m}$. Regional biases associated with geoid, orbit and topography-induced errors reduce the accuracy of the height measurements. This was assessed by a comparison with ground-survey data. The DEM was compared with a $700 \mathrm{~km}$ levelling survey, with an accuracy ranging from $\mathrm{l}$ to $5 \mathrm{~m}$, from the Lambert Glacier basin region $\left(\approx 73^{\circ} \mathrm{S}, 55^{\circ} \mathrm{E}\right)$. The mean difference was found to be $-1.6 \mathrm{~m}$ with a standard deviation of $14 \mathrm{~m}$. A similar result was obtained for a $600 \mathrm{~km}$ traverse line in Wilkes Land $\left(75^{\circ} \mathrm{S}, \approx 110^{\circ} \mathrm{E}\right)$.

The DEM was then compared with a digitized version of the Scott Polar Research Institute (SPRI) Antarctic folio map. This map was derived from orthometric measurements of surface elevation, primarily from pressure altimetry. Differences in excess of $300 \mathrm{~m}$ were observed between the two data sets. Only $37 \%$ of the region covered showed agreement to better than $50 \mathrm{~m}$, and a significant proportion of this was composed of the Ross and Filchner-Ronne Ice Shelves. The largest discrepancies occurred in marginal areas where there is poor coverage by both satellite altimetry and terrestrial data. Inland, significant differences were also found.
\end{abstract}

\section{INTRODUGTION}

Accurate topographic maps of the polar ice sheets are an invaluable input into, and test of, models of their dynamic behaviour (e.g. Huybrechts, 1990). They provide useful information on the morphology of the ice sheet and can be used to delineate drainage basins and flowlines (Drewry, 1983). This information can, in turn, provide information about the ice rheology.

Due to its size and remoteness, however, Antarctica has relatively poor coverage by ground-based surveys. Consequently, large areas, especially the East Antarctic ice sheet, have a paucity of terrestrial elevation measurements (Drewry, 1983). Where there are data, they are mostly barometric estimates from pressure altimetry either from radio-echo sounding (RES) flights or oversnow traverses. Such measurements are prone to signif-icant errors which, in general, become larger the farther inland they are made. This is because they are usually referenced to mean sea level (m.s.l.) at the coast (Steed, 1980).
The use of satellite radar-altimeter data to derive surface heights over ice sheets is now well established (e.g. Brooks and others, 1978; Zwally and others, 1983). However, until the launch of ERS-1 in July 1991, the coverage has been limited to a latitude of $72^{\circ} \mathrm{S}$. This has allowed accurate topographic mapping of a number of marginal ice shelves (e.g. Partington and others, 1987; Ridley and others, 1989) and part of Terre Adélie (Remy and others, 1989). The two largest ice shelves - the Filchner-Ronne and Ross Ice Shelves - and much of the interior of the ice sheet, however, remained uncharted by satellite altimetry. The coverage of ERS-1 extends to $81.5^{\circ} \mathrm{S}$ and therefore provides useful height data over much of the East Antarctic ice sheet and the West Antarctic ice shelves. This paper presents some of the first results of topographic mapping of the ice sheet and compares these with previous estimates of surface elevation from terrestrial measurements. A comparison with recent levelling surveys provides confirmation of the accuracy of the altimeter data. 


\section{DATA ANALYSIS AND REDUCTION}

\section{Altimeter data}

ERS-1 altimeter data are distributed in two forms. The first, distributed as wave-form data, comprises a comprehensive data set with corrections, quality flags and wave forms at the full sampling rate of $20 \mathrm{~Hz}(335 \mathrm{~m}$ alongtrack). At present, however, only limited amounts of these data are available. The second are known as the fastdelivery (FD) data and are a summary product, with a reduced spatial resolution of $6.7 \mathrm{~km}(1 \mathrm{~Hz})$ along-track. No wave forms are included and a relatively limited range of other parameters is provided.

In this study, four $35 \mathrm{~d}$ repeats of $\mathrm{FD}$ data were used (cycles 83, 85, 87 and 89), comprising approximately 1000000 measurements of surface elevation over the Antarctic continent. These data were improved with the use of ESA precise orbits, which are available approximately 3-6 months after acquisition (ESA, 1992).

In the absence of wave forms, it is necessary to carry out careful filtering to remove erroneous data. Several criteria were used, based on ancillary parameters included in the data. One of these is the "pulsepeakiness" parameter, which can be used to determine whether a leading edge is present within the range window of the altimeter. Only data with peakiness values between 1.0 and 2.5 were accepted. These valucs were chosen after a detailed analysis of the performance of the ERS-1 altimeter using wave-form data (Scott and others, 1992). A standard deviation of range is also included in the product, derived from the 20 samples that comprise the $1 \mathrm{~Hz}$ averaged data. Large values of this parameter indicate poor tracking and/or complex surface returns. Data with a standard deviation range of greater than $25 \mathrm{~m}$ were also discarded. These two filters removed almost $40 \%$ of the data. A larger proportion was removed from the marginal areas where the slopes are higher and the tracking performance of the altimeter is, consequently, worse.

Analysis of cross-over data (discussed later) indicated, however, that a small percentage of erroneous elevations was still being included and a further stage of filtering was required. The data were gridded into a DEM by calculating the mean value of elevation from all data within a radius of $10 \mathrm{~km}$ from the grid point. If no data were present, then bilinear interpolation, using neighbouring grid points, was used up to a maximum radius of $50 \mathrm{~km}$ to estimate the height at the grid point. Finally, the grid was smoothed using quadratic interpolation. From the gridding procedure, it was possible to derive standard deviations $(\sigma)$ for each grid point based on the difference in elevation of the grid value and the altimeter measurements used in calculating it. Data with elevations greater than $3 \sigma$ from thcir respective grid-point value (after taking into account any displacement from the grid, by bilinear interpolation) were discarded. Although this is not, strictly, a test for erroneous data, this approach was found to remove gross outliers, which had not been identified in the previous filtering steps.

A repeat-track analysis was also used to remove outliers. A repeat track is the identical revolution in a particular cycle of orbits. In this case, four cycles of $35 \mathrm{~d}$ repeat data were available, providing four repeat tracks for every revolution. The mean and standard deviation were calculated from the sum of the four values for each point, using linear interpolation to account for offsets in the along-track positions of the points. Where less than four points were available, no standard deviation was estimated. These two additional steps in data filtering removed a further $1 \%$ of erroneous points.

The data coverage, after filtering, for one of the $35 \mathrm{~d}$ repeats is shown in Figure 1. It is similar for the other repeats. One of the most obvious features of Figure 1 is the excellent coverage of the ice shelves and the relatively poor coverage of the marginal areas with higher slopes. For example, there are relatively few data over the Antarctic Peninsula, as is the case for the Transantarctic Mountains and other mountainous regions such as Prince Charles Range and Fimbulheimem. A comparison with a plot of surface slopes (calculated from the DEM) indicates a high degree of correlation between areas with poor data coverage and slope. With the use of wave-form data (allowing more precise data filtering) and a more robust tracking facility of the ERS-1 altimeter known as "ice mode" (which is available only for wave-form data), many of the areas with few data will have improved coverage (Scott and others, 1992).

A slope-induced error correction was applicd by the relocation method (Brenner and others, 1983), using a procedure described elsewhere (Bamber, 1994). The method takes into account Earth curvature and uses all the data to produce a data base of slope cells. The DEM was recalculated after the final filtcring and slope correction and the OSU91-A geopotential model (Rapp and others, 1991) was used to convert the elevations into values relative to the geoid. A polar stereographic projection, with origin at the South Pole, and standard parallel of $71^{\circ} \mathrm{S}$ was used to translate from polar to Cartesian coordinates. The grid spacing was $20 \mathrm{~km}$. This is identical to the format of a digitized version of the SPRI

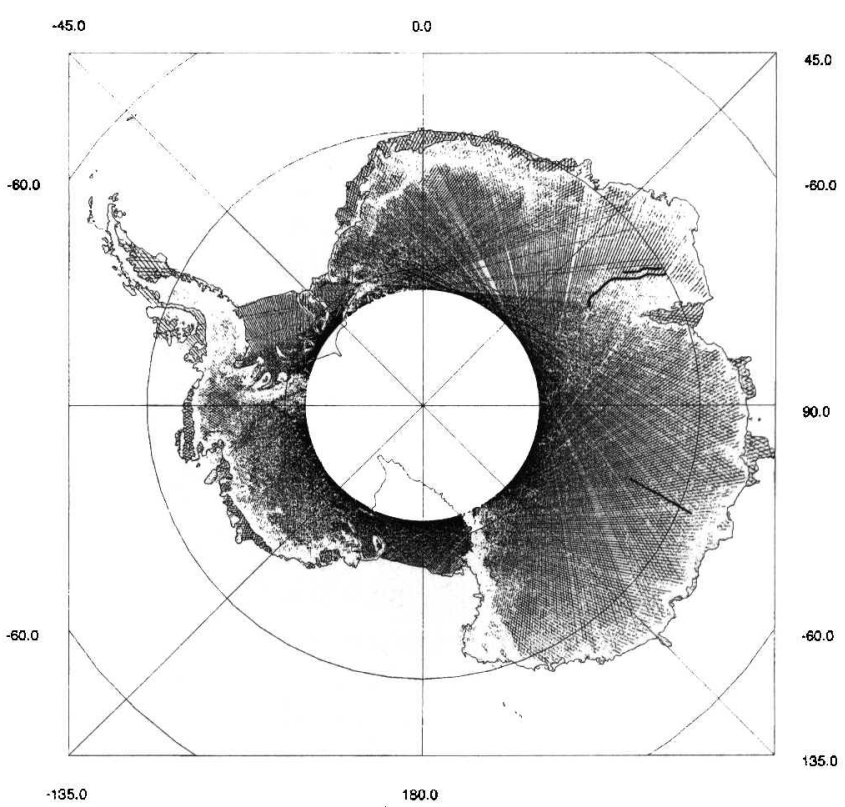

Fig. 1. Radar-altimeter coverage, after filtering, for one 35 repeat. Also shown as heavy lines are the locations of the levelling surveys discussed in the text. 
folio map (Budd and others, 1984) and, consequently, allows for a quantitative comparison between the two. Gridding at a higher resolution provides more detailed information for studies of specific areas (e.g. Bamber and Bentley, 1994), although the differences would not be seen on a map of the whole ice sheet as the elevation range is too great.

\section{Error sources}

The crrors in the satellite-altimetcr estimate of clevation comprise two components: $E=E_{\text {random }}+E_{\text {bias }}$.

\section{Random errors}

The orbit and atmospheric errors associated with the FD data amount to about $60 \mathrm{~cm}$ and have been discussed elsewhere (Bamber and Bentley, 1994). There is a random and systematic error due to not recalculating the range estimate, a process known as retracking (Martin and others, 1983), which can only be carried out on wave forms. The magnitudes of these errors were assessed by calculating the mean and standard deviation of the retracking correction obtained from a small data set of wave forms ovcr Antarctica. A thrcshold retracking technique Bamber, 1994) was used and the mean corrcction was found to be $-0.44 \pm 0.91 \mathrm{~m}$, at the $95 \%$ confidence limit, for 150000 wave forms.

The combined random errors can be determined from a comparison of crossing points of descending and ascending orbits. The standard deviation of 43864 crossovers was $6.8 \mathrm{~m}$. If this is the random component of the hcight error on two measurements, then combining four repeat tracks reduces the error on a single elevation estimate to $2.4 \mathrm{~m}$. The cross-over differences were contoured to indicate the regional distribution of the random height error. Areas with no cross-overs, or high values, were found in regions of high relief such as around the margins and along the Transantarctic Mountains and indicate poor tracking and, consequently, higher height errors.

\section{Biases}

The gcographically correlated orbit error and uncertainties in the geoid amount to about $2 \mathrm{~m}$ and have bcen discussed, in detail, elsewhere (Bamber and Bentley, 1994). There is a $0.44 \mathrm{~m}$ bias due to not applying a retracking correction (discussed earlicr) and this is also likely to be geographically correlated as the bias is a function, primarily, of surface slope (Bamber, 1994).

\section{Slope-correction errors}

The slope-correction procedure groups the data into rectangular cells (Bamber, 1994). 'The data in each cell are then fitted to a plane by a least-squares method. Due to the relativcly coarse spatial resolution of the $F D$ data $(6.7 \mathrm{~km})$, it was necessary to make the ccll size $25 \mathrm{~km}$ by $35 \mathrm{~km}$. Undulations within each cell will, therefore, be smoothed out to a mean value for the whole cell. 'To assess the errors in slope correction, the standard deviation of the fit parameters in each cell was determined using a singular value decomposition algorithm (Press and others,
1986). It was not possible to do this for every cell due to the volume of data required, so a sub-set of cells was selected along four longitude lines $45^{\circ}$ apart from cach other. For the 306 colls selected in this manner, the standard deviation was $0.11 \mathrm{~m}$ for a mean correction of $4 \mathrm{~m}$.

In regions where there is poor data coverage (Fig. l), the error on slope correction is larger than the valuc quoted above. Furthermore, for slopes greater than $0.65^{\circ}$ (the half-power beam width of the altimeter antenna), the elevation estimates are not reliable for two primary reasons. First, the data coverage in these areas is poor. 'l'his, in turn, leads to a poor estimate of the local slope and, hence, a large error in slope correction. Secondly, the antenna pattern drops off rapidly beyond $0.65^{\circ}$ and the returned power is, therefore, much lower than for flatter areas. Regions with slopes greater than $0.65^{\circ}$ represent, however, only $8.7 \%$ of the ice-sheet area covered.

\section{Errors in the terrestrial data set}

The SPRI folio surface-elevation map was derived from a number of data sources, primarily pressure altimetry from RES flights. Changes in surface pressure due to weather systems can produce errors of up to $150 \mathrm{~m}$ in elevation over distances of a few hundred kilometres (Steed, 1980). Using a random-walk procedure, however, it has been estimated that the RES surface elevations are accuratc to better than $50 \mathrm{~m}$, with positional errors of $\ll 5 \mathrm{~km}$ (Drewry and others, 1982). The free-floating constantdensity balloons (TWERIE data; Levanon and others, 1977) that were used in the folio map are believed to be accurate to $60 \mathrm{~m}$ in elevation.

Much of the terrestrial data were referenced to m.s.l. This is not always the same as the elevation of the geoid which, for Antarctica is assumed to be roughly $1.5 \mathrm{~m}$ above m.s.l. (personal communication from R.H. Rapp, 1993). Furthermore, there are short time-scale fluctuations in m.s.l. due to cddies and tides which can amount to several metres in shallow continental shelf water.

A DEM of the SPRI folio elevations was produced by digitizing the 1:6000000 scale map (Budd and others, 1984). A $1 \mathrm{~mm}$ error in the digitization point introduces a $600 \mathrm{~m}$ error in position or a $7 \mathrm{~m}$ error in elcvation (for the maximum surface slope considered here of $0.65^{\circ}$ ). This is insignificant with respect to the data errors. However, the original map used had folds in it, which produce small distortions when flattened, and it is not known what quality control was used when digitizing. From the digitized contours, the data were gridded into a DEM by an unknown procedure. To determine the effect of these various processes, values from the DEM were compared with the original folio map for two transects running east-west and along the zero meridian through the South Pole. Differences of up to $90 \mathrm{~m}$ were found and for the 33 points sampled the mean difference was $10.7 \pm 44 \mathrm{~m}$. A signif-icant clement of the error in this data set is due, therefore, to the digitization and/or gridding process. Furthermore, these errors are not randomly distributed and tend to be larger in areas of higher slope. 


\section{RESULTS}

To provide the maximum visual definition, the altimeterderived DEM is displayed as a shaded isometric plot. Figure 2 is a view from the south with the Ross Ice Shelf in the foreground. Roosevelt Island and the southern tip of Siple Dome are visible, as is the subglacial lake at Vostok Station (the crescent-shaped shadow on the central part of the plateau).

South of $81.5^{\circ}$, the SPRI DEM was used to fill in the missing data. There are two attributes of this data set that are immediately obvious. First, there is a step in elevation between the altimetric heights and the folio values (discussed later). Secondly, it is evident that the level of detail in the altimeter data is much greater - the surface of the folio DEM is smoothly varying in comparisondespite being gridded with the same spacing. A finer grid spacing in the altimetry, used on smaller areas, has revealed even greater detail about the morphology of the ice sheet and ice shelves (e.g. Bamber and Bentley, 1994). The altimeter DEM is also displayed in a planimetric view in Figure 3. In this perspective, the ice divides stand out very clearly. Ridge B appears to flatten out before reaching Dome Argus, which itself secms to be flat. Again, the subglacial lake at Vostok is identifiable. There appears to be good agreement between the two DEMs for the location of the ridge from Hercules Dome on to the West Antarctic ice sheet but the discrepancy in elevations in the east is clearly visible.

To obtain a quantitative estimate of the degree of

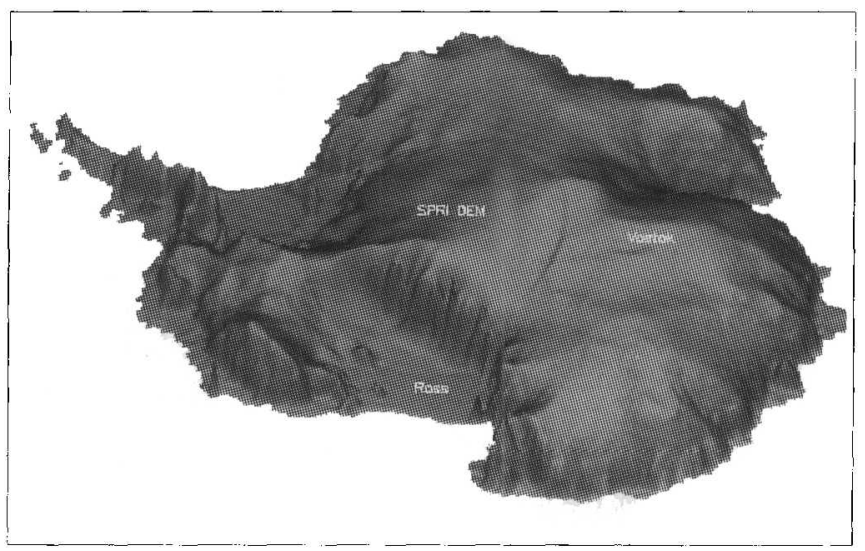

Fig. 2. Shaded isometric view from the south with the Ross Ice Shelf in the foreground. The area south of $81.5^{\circ}$ has been filled in with the SPRI folio DEM. The surface expression of the subglacial lake is visible as a cresentshaped shadow on the central part of the plateau.

agreement between the two data sets, a difference plot was produced by subtracting the SPRI folio DEM from the radar-altimeter DEM (Fig. 4). Where the local slopes (on a $40 \mathrm{~km}$ scale length) were $>0.65^{\circ}$, no value was estimated and appears in white in the figure. Differences in excess of $200 \mathrm{~m}$ are evident. This is approximatcly four times the combined rms measurement error of the data $(\approx 50 \mathrm{~m})$. Regions which lie within the rms errors represent only $37 \%$ of the arca covered by the satellite

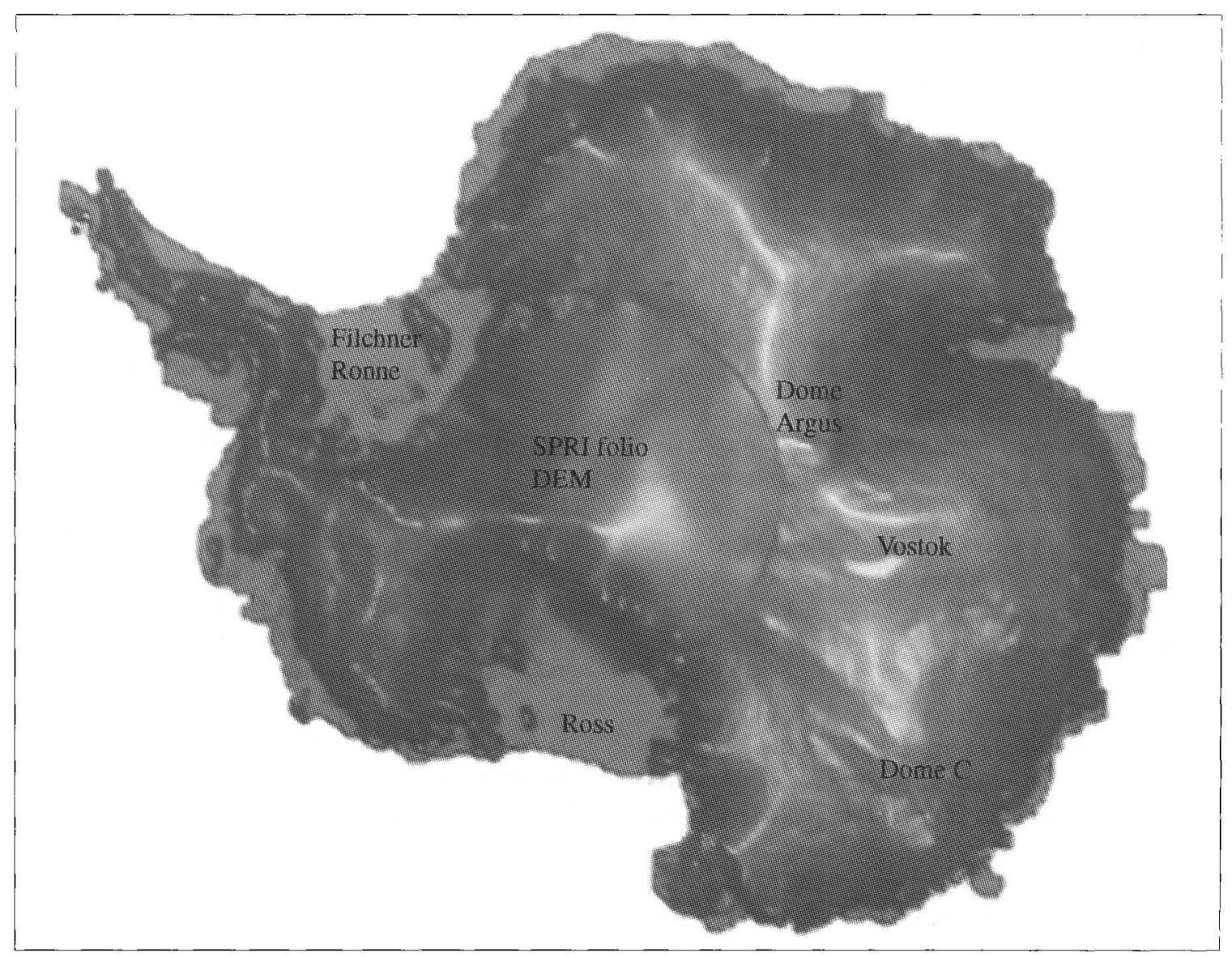

Fig. 3. Planimetric, shaded view of the Antarctic ice sheet from ERS-1 radar altimetry. South of $81.5^{\circ}$, the SPRI folio DEM has been used. 


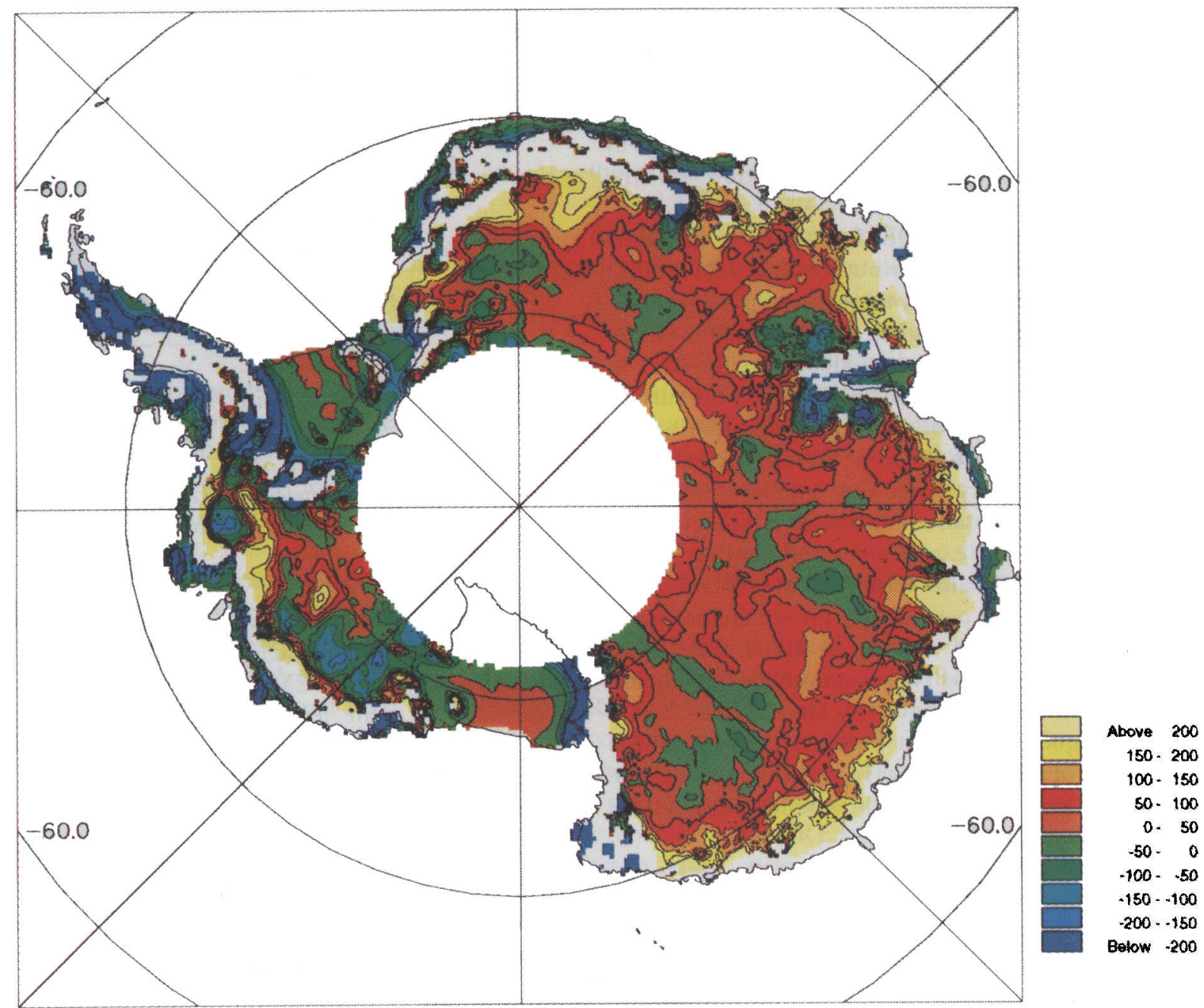

Fig. 4. Map of altimeter-SPRI folio DEM differences for areas with a slope $<0.65^{\circ}$. The contour interval is $50 \mathrm{~m}$.

and a significant proportion of this is due to the two major ice shelves, the Filchner-Ronne and Ross Ice Shelves. 'The other main area where agrcement is better than $50 \mathrm{~m}$ is in the vicinity of Dome $\mathrm{C}$ and south of George $\mathrm{V}$ Land, again where there is a good RES coverage. There are two bands of low differences which start about $300 \mathrm{~km}$ south of Casey and Mirnyy Stations and seem to coincide with the location of a satellite Doppler-positioning traverse and a geodetic levelling traverse, respectively. The other area of agreement $(<50 \mathrm{~m}$ difference) is to be found in southern Dronning Maud Land. This is surprising given the relative dearth of terrestrial data - a sparse distribution of geodetic levelling data and no RES flight lines.

The worst agreement (differences of $>100 \mathrm{~m}$ ) tends to exist in regions where there is poor coverage of terrestrial data and/or in coastal regions. These areas include much of the Antarctic Peninsula, Dronning Maud Land, the region around Valkyrjedomen and a large part of Wilkes Land west of about $110^{\circ} \mathrm{E}$. Differences of $100 \mathrm{~m}$ are found in the relatively flat area south of the Amery Ice Shelf in the vicinity of Dome Argus (Fig. 4), most probably due to the large distance from the coast $(\approx 1000 \mathrm{~km})$ and the paucity of ground data. Along the East Antarctic coast there are some differences in excess of $200 \mathrm{~m}$. Examination of the coverage of terrestrial data indicates that from Casey $\left(\approx 111^{\circ} \mathrm{E}\right)$ to Mawson Station $\left(\approx 64^{\circ} \mathrm{E}\right)$ there are only a handful of measurements across the coastline, and up the steepest part of the ice sheet. All the way round to Coats Land $\left(30^{\circ} \mathrm{W}\right)$, the distribution of coastal points is sporadic. However, in these areas, the altimeter and digitization errors are larger and it is, consequently, not so clear what the dominant error is. Even where there is good coverage of terrestrial data, such as in Enderby Land or Terre Adélie, the differences are still large, suggesting that the altimeter DFM may be in error in these regions. However, in a previous study using Seasat wave-form data, differences in excess of $100 \mathrm{~m}$ have been reported between the satellite altimetry and terrestrial data in Terre Adélie (Brooks and Norcross, 1982; Remy and others, 1989).

Differences in excess of $200 \mathrm{~m}$ can be seen in a small region centred at about $78^{\circ} \mathrm{S}, 112^{\circ} \mathrm{W}$. Such an increase in surface elevation would be, presumably, reflected by an equivalent increase in bedrock elevation, which is bclow sea level (b.s.l.) in this region. It is possible, therefore, that the area of ice grounded b.s.l. might be reduced with the use of accurate surface-elevation data. 


\section{COMPARISON WITH GROUND-TRUTH DATA}

The observed differences are significantly larger than expected, given the estimated errors for the two data sets. Some of this can be attributed to the digitization of the folio map. Given the magnitude of the differences, however, it was considered desirable to "validate" the models against an accurate and independent (i.e. data not used in the generation of either DEM) ground traverse in an area where the differences were significant $(>50 \mathrm{~m})$. Three geodetic levelling data sets were obtained. Their locations are shown in Figure 1. The first two (which will be referred to as the Lambert traverses) lie to the south and east of the Amery Ice Shelf and were collected during the austral summers of 1991-92 and 1992-93. The height estimates were obtained from GPS measurements every $30 \mathrm{~km}$, with barometric elevations every $8-15 \mathrm{~m}$ in between. At control stations, the accuracy is $1-2 \mathrm{~m}$, rising to $5 \mathrm{~m}$ at the midpoint between controls (personal commmunication from M. Higham, 1993).

DEM elevations at the traverse points were calculated using a bilinear interpolation procedure. A plot of the longer of the two Lambert traverses is shown in Figure 5a. No ground-traverse data were available between 470 and $550 \mathrm{~km}$ along-track, and this is the reason for the break in the plot. Good agreement is obtained between the altimeter DEM and the traverse. The mean difference (altimeter-ground traverse) is $-1.3 \mathrm{~m}$ with a standard
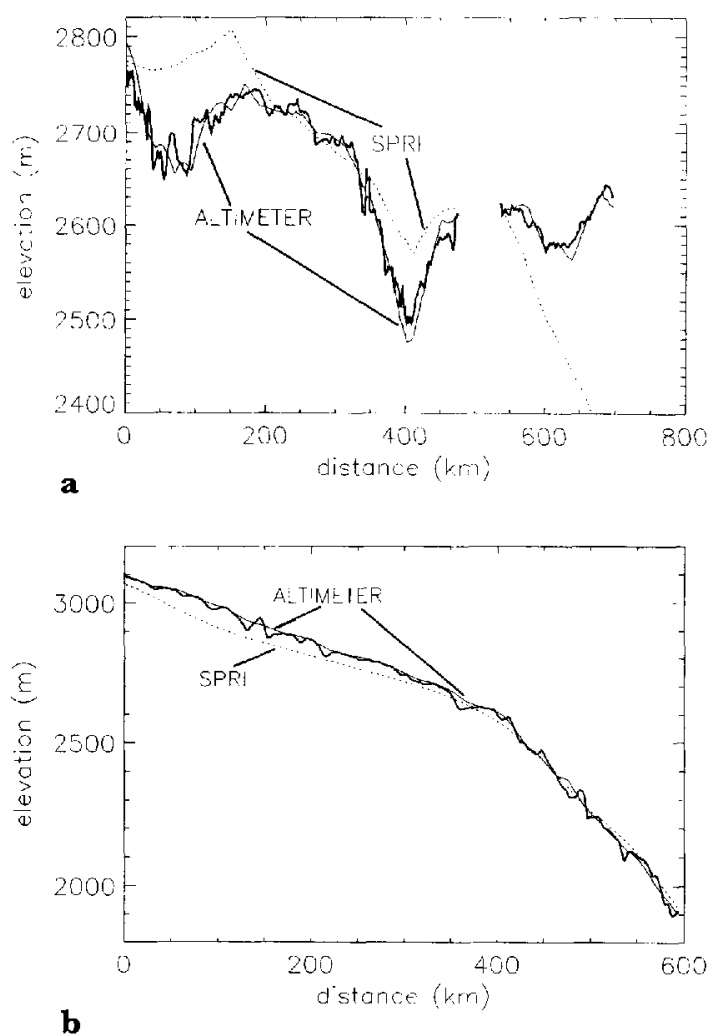

Fig. 5. a. A comparison between the altimeter and folio $D E M$ (dotted line) elevations and the longer of the two levelling traverses (thick line) in the Lambert Glacier basin region. There is a break in the ground-traverse data at about $470 \mathrm{~km}$ along-track. $b$. A comparison between the allimeter and folio DEM (dotted line) elevations and the levelling traverse (thick line) in Wilkes Land. deviation of $14 \mathrm{~m}$. As can be seen from the plot, the magnitude of the standard deviation is partly due to the short wavelength $(<20 \mathrm{~km})$ undulations in the traverse data, which have been smoothed out in the DEM. The mean difference lies well within the combined measurement errors. A very similar result is obtained for the Wilkes Land traverse (mean difference $3 \mathrm{~m}$, standard deviation $15 \mathrm{~m}$ ) and this is shown in Figure 5b. This confirms the error estimates made for the altimeter elevations for slopes $<0.65^{\circ}$.

It can be seen that the SPRI folio DEM deviates from the traverse data by as much as $250 \mathrm{~m}$. To determine whether these differences werc due to the digitization process, the elevations were recalculated from the original SPRI map at the locations of maximum deviation from the traverse data. Depending on the location, the differences were due solely to digitization, errors in the original map or a combination of the two.

It is hoped that most of the digitization errors will have been removed in a more recent compilation of terrestrial elevation data known as the Antarctic Digital Database (Cooper and others, 1993). This data base has becn compiled with the most recent maps of the coastline and should provide a considerably improved DEM in the marginal areas compared with the SPRI folio. In the interior, however, the data are primarily derived from the folio. The data base was, unfortunately, not available for this study.

\section{SUMMARY}

A DEM up to a latitudinal limit of $81.5^{\circ} \mathrm{S}$ has been produced providing unparalleled accuracy for surface elevations south of $72^{\circ}$. Comparison with levelling surveys indicates that the mean error is on the order of a few metres for the interior of the ice shect. It is believed that this DEM provides a considerable improvement on previous topographic maps of surface elevation. To allow comparison with the SPRI folio DEM, the altimeter data were gridded with a $20 \mathrm{~km}$ spacing. However, the data have also been gridded with a $10 \mathrm{~km}$ spacing to allow better definition of topographic features. This data sct is available for scientific applications.

The differences seen between the DEM derived from terrestrial data and the satellite altimetry have been attributed to several causes, including the paucity of terrestrial measurements for large areas of the ice sheet. The cause of the large differences (>200 $\mathrm{m}$ ) along the East Antarctic margins cannot be uniquely identified due to the relatively poor coverage by the satellite data in this region. The use of wave-form and ice-mode data, however, combined with better atmospheric corrections, will provide a substantial improvement in accuracy and coverage, especially in the margins. The inclusion of these data in the production of an improved DEM is currently under way.

Detailed investigations of specific areas are also under way using wave-field migration techniques, removing the need for slope correction and retracking. Furthermore, this work offers the potential of resolving undulations on a much shorter wavelength than is possible by more conventional approaches (Wingham and others, 1993). 


\section{ACKNOWLEDGEMENTS}

The author would like to thank colleagues at MSSL for useful discussions and assistance, J. Morley for help with the slope-correction software, M. Higham, M. Reynolds and R. Kiernan for providing the Lambert traverse data, and N. Young for providing the Wilkes Land traverse data. Funding for J.I.B. was through a U.K. NERC grant GR3/7836.

\section{REFERENGES}

Bamber, J. L. 1994. Ice sheet altimeter processing scheme. Int. 7. Rem. - Sens., 20(15), 925-938.

Bamber, J.L. and C.R. Bentley. 1994. A comparison of satellite altimetry and icc-thickness measurements of the Ross Ire Shclf, Antarctica, Ann. Glaciol, 20 (see paper in this volume).

Brenner, A. C., R.A. Bindschadler, R. H. Thomas and H.J. Zwally. 1983. Slope-induced crrors in radar altimetry over continental ice sheets. 7. Geophys. Res., 88(C3), 1617-1623.

Brooks, R. L. and G. A. Norcross. 1982. East Antarctic ice sheet surface contours from satcllite radar altimetry - a demonstration. Salisbury, MD, Geoscience Research Corp.

Brooks, R. L., W. J. Campbell, R. O. Ramseier, H. R. Stanley, and H. J. Zwally. 1978. Ice sheet topography by satellite altimetry. Vaiure, 274(5671), 539-543

Budd, W.F., D. Jenssen and I. N. Smith. 1984. A three-dimensional time-dependent model of the Antarctic ice sheet. Ann. Glaciol, 5, 29-36.

Cooper, A. P. R., J.W. Thomson and E. M. Edwards. 1993. An Antarctic GIS; the first step. GIS Europe, 2(6), 26-28.

Drewry, D. J. 1983. Antarctica: glaciology and geophysical folio. Cambridge, University of Cambridge. Scott Polar Rescarch Institute.

Drewry, D.J., S.R. Jordan and E. Jankowski. 1982. Measured properties of the Antarctic ice sheet: surface configuration, ice thickness, volume and bedrock characteristics. Ann. Glaciol., 3, 83-91.
European Space Agency. 1992. ERS-1 system. ESA SP-1 146.

Huybrechts, P. 1990. A 3-D model of the Antarctic ice shect: a sensitivity study on the glacial-interglacial contrast. Clim. Dynam., 5(2), 79-92.

L.cvanon, N., P. R. Julian and V.E. Suomi. 1977. Antarctic topography from balloons. Nature, 268(5620), 514-516.

Martin, T.V., H.J. Zwally, A. C. Brenner and R.A. Bindschadler. 1983. Analysis and retracking of continental ice shect radar altimeter waveforms. J. Geophys. Res, 88(C3), 1608-1616.

Partington, K. C., W. Cudlip, N. F. McIntyre and S. King-Hele. 1987. Mapping of Amcry Ice Shelf, Antarctica, surface features by satellite altimetry. Ann. Glaciol, 9, 183-188.

Press, W.H., B.P. Flannery, S.A. Teukolsky and T.W. Vetterling. 1986. Numerical recipes: the art of scientifir computing. Cambridge, Cambridge University Press.

Rapp, R.H., Y. M. Wang and N. K. Pavlis, 1991. The Ohio State 1991 geopotential and sea surface topography harmonic coefficient models No. 410. Columbus, OH, Department of Geodetic Science and Surveying, Ohio State Cniversity.

Remy, F., P. Mazzega, S. Houry, C. Brossier and J, F. Minster. 1989. Mapping of the topography of continental ice by inversion of satellite-altimeter data. J. Glaciol., 35(119), 98-107.

Ridley, J. R., W. Cudlip, N. F. McIntyre and C. G. Rapley. 1989. The topography and surface characteristics of the Larsen Ice. Shelf, Antarctica, using satellite altimetry. 7. Glaciol, 35 121), 299-310.

Scott, R. and 13 others. 1992. An investigation of the tracking performance of the ERS-1 radar altimetcr over non-occan surfaces. UK-PAF Report No. PF-RP-MSL-AL-0100), ESA-FSRIN.

Stced, R. H. N. 1980. Geophysical studies of Wilkes Land, Antarclica. (Ph.D. thesis, University of Cambridge.)

Wingham, D.J., C.G. Rapley and J.G. Morlcy. 1993. Improved resolution ice shect mapping with satellite radar altimeters. EOS, 74 (10), $113-116$.

Zwally, H.J., R.A. Bindschadler, A. C. Brenner, T. V. Martin and R.H. Thomas. I983. Surface devation contours of Greenland and Antarctic ice sheets. 7. Geophys. Res., 88(C3), 1589-1596.

The accuracy of references in the lext and in this list is the responsibility of the author, to whom queries should be addressed. 